\title{
AN ANALYSIS OF SOME EVIDENTIAL STRUCTURES IN ESSAYS WRITTEN BY STUDENTS OF FRENCH AS A FOREIGN LANGUAGE ${ }^{1}$
}

\author{
Elisabeth Miche \\ Pompeu Fabra University, Barcelona
}

\begin{abstract}
:
In this article, we perform an evidential analysis of three types of construction taken from essays written by students of French as a foreign language: the shown source, the quoted source and borrowed knowledge. The issue with these constructions, which refer to passages from a book, is knowing the extent to which they have an evidential value because, within the context of our analysis, the source and the knowledge reference overlap. We defend an evidential reading of these segments given their argumentative function in the students' discourse. We perform a pragmatic analysis of these language forms that take into account the parameters of the communicative situation and the type of text that the students have to produce. Our hypothesis is this: the figure of the teacher (who, in this case, is the hearer and the addressee) and his or her instructions have a direct impact on the way in which the student presents his or her knowledge of the book on which he or she is commenting. The analysis of the function of these three forms has also led us to address the issue of the relationship between evidentiality and notions like the reliability and epistemic modality. We conclude that source (evidentiality) is a reliability's character and an epistemic function in the discourse.
\end{abstract}

Keywords: evidentiality, epistemic modality, commitment, utterance, pragmatics, argumentation.

\section{Introduction}

This study is about three types of language unit appearing in essays written by students of French as a foreign language (FFL) on the book entitled $N i$ d'Ève ni d'Adam (Tokyo Fiancée) by Amélie Nothomb. The shown source, the quoted source and borrowed knowledge. The common feature of these units is that they refer to passages from the novel. The issue is knowing whether to consider them as evidential units because they do not express anything about how the speaker actually knows what he or she is saying. In fact, the question about the source of knowledge is not relevant to our analysis as the book-reading stage necessarily precedes the essay-writing stage. The source of knowledge is therefore shared by the speakers and the hearer/addressee alike. However, if those units are considered to be the perceptual and/or epistemological bases (in the sense of references) on which or from which the speakers attempt to describe the characters, then they can also be considered 
evidential units. That is the approach we have taken. The three types of structure, which are analyzed in point 4, are: 1) discourse segments introduced by a colon; 2) quotes of passages from the book introduced by the lexemes "for example" (par exemple) and "like" (comme), and; 3) sequences introduced by the borrowed knowledge marker "according to X" (selon X).

Until now, most studies on evidential or mediative ${ }^{2}$ marking have focused on grammatical and lexical units that, in one way or another, show the type of information source. There are studies on modal verbs in French (Dendale 1994, Barbet 2012), on verb tenses (Dendale 1993, Guentchéva 1994), on adverbs (Miche \& Lorda 2014), on prepositions (Borillo 2005, Coltier \& Dendale 2004, Schrepfer 2005). However, analysing the pragmatic functions of language units carrying evidential meaning has not previously been the object of much attention, except for the studies by González (2011) and Saussure (2012).

The aim of this study is, therefore, to focus on the pragmatic, discursive and argumentative dimensions of the three types of language unit mentioned above. Several questions have served as a guide for our analysis. What is the function of evidential marking? Why is it that students use this type of evidential sequence rather than modal markers or personal evidential markers? Is there any specific type of evidentiality that may be due to the type of discourse being analyzed? Our work is based on the assumption that every student statement took its hearer/addressee into consideration, and it aims to establish the extent to which the teacher (who, in this case, is the hearer and the addressee) and his or her instructions may have had a direct influence on the way the students presented their knowledge of the novel about which they wrote.

This study is neither quantitative nor qualitative. It is not our intention to show which of the forms is used the most by the students to refer to the source of their description, but instead to enrich reflection on the issue of evidentiality, epistemic modality and speaker commitment in his or her discourse by analysing these three linguistic forms.

In order to make our arguments clearer, we are going to state the definition of evidentiality and the criteria used to defend an evidential reading of these linguistic structures.

\section{Theoretical framework}

\subsection{The notion of evidentiality}

"Evidentiality" is generally understood as the linguistic phenomenon that shows "how one has knowledge of what one is saying" (Hardman 1986: 115). It is therefore a functional category referring "to the perceptual and/or epistemological basis for making a speech act" (Cornillie 2009: 45). Take the example given below: 
(1) Pierre est dans son bureau. Je l'ai vu entrer.

[Pierre is in his office. I saw him go in.]

Here, to the assertion Pierre is in his office, the speaker adds the means by which he or she knows or is able to affirm that this is so: I saw him go in.

Similarly, the following example (2) deals with evidentiality since the verb of perception "to find" (trouver) provides semantic pointers as to how the speaker reached the conclusion this film is very sad (Ducrot 1980: 77). Specifically, “to find” (trouver) marks the speaker's opinion, which comes from a personal judgment formed on the basis of his or her own experience; he or she is the actual origin of the source of his or her knowledge.

(2) Je trouve que ce film est très triste.

[I find that this film is very sad.]

Linguistic literature has traditionally classified evidentiality as direct or indirect (Cornillie 2009, Dendale \& Tasmowski 2001). Direct evidentiality markers are those that, as in example (1), show that the speaker has witnessed the action that he or she conveys, whereas indirect evidentiality markers show that the speaker has not witnessed the action, but instead has become aware of it by deduction or hearsay. When the action is deduced, one talks of inference, and when information about the action comes from people other than the speaker, one talks of hearsay markers, reportatives or quotatives.

In the following, we propose a relativist definition of evidentiality, that is to say, a definition of evidentiality adapted to our object of study. Since the issue of "how one has knowledge of what one is saying" is not relevant in our context (because the how is achieved by reading the book), we will introduce why the speaker thinks what he or she thinks and why the speaker says what he or she says as a variant into that canonical definition.

\subsection{Epistemic modality}

The epistemic category refers to "the evaluation of the chances that a certain hypothetical state of affairs under consideration (or some aspect of it) will occur, is occurring or has occurred in a possible world" (Nuyts 2001: 21). The evaluation may range from absolute certainty to absolute certainty of 
non-reality (not real). Between the two extremes, there is a continuum ranging from probability to possibility, e.g., "undoubtedly" (sans doute) in example (3) below:

(3) Pierre est sans doute arrivé (car il y a de la lumière chez lui).

[Pierre has undoubtedly arrived (because the light is on inside his house).]

The epistemic adverb "undoubtedly" (sans doute) marks the speaker's belief in Pierre's arrival, and he or she qualifies it as probable. This information is probable because it has been inferred by the speaker due to a sign: the light ${ }^{3}$. Since the relationship of implication between the sign and the conclusion has not been verified, the speaker cannot express his or her certainty. In fact, the light could be on for other reasons. For example, someone other than Pierre may have gone into his house. It is therefore at the precise point of the nature or the mode of knowledge (evidentiality) that the close relationship between the notion of evidentiality and epistemic modality is established. Furthermore, the mode of knowledge sometimes has certain implications for knowledge reliability or guarantees. While it is not our intention to get into the debate about knowing whether the relationship between these two notions is inclusive, exclusive or overlapping (regarding this issue, we would refer the reader to the articles by Dendale \& Tasmowski (2001), Kronning (2004) and Cornillie (2009)), we would nevertheless like to reflect on the idea — already raised by Cornillie (2009) — that these dimensions meet, in our case, at the point of the idea of knowledge reliability (evidentiality) and speaker commitment (epistemic modality). "Rather than representing a concrete overlapping domain, epistemic or evidential expressions may more accurately be described as having similar subdimensions that meet at some point" (Cornillie 2009: 51). The notions of evidentiality and epistemic modality are, therefore, conceptually different yet closely linked domains. While evidentiality refers to the process of reasoning that underpins the proposition, epistemic modality evaluates the proposition in terms of likelihood or degrees of probability.

\subsection{The notion of (non-)commitment}

We have decided to make a clear separation of the notions of "epistemic modalization" and "(non-) commitment". The latter is taken as being alethic. We can say that the speaker "commits" to his or her utterance if this utterance is presented as being "true for the speaker", and that the speaker does not commit to his or her utterance whenever this utterance is "neither true nor false for the speaker". In this respect, the notion of (non-)commitment is equivalent to the notion of Kronning's (2004: 44) simple modalization. By uttering, the speaker asserts and presents the utterance as true, "showing" 
the truth of its propositional content. This is also the viewpoint of Dendale and Tasmoski in their studies on devoir (must) (Dendale 1994), and pouvoir (can) (Dendale \& Tasmowski 1994), and of Schrepfer (2005) in his analysis of the epistemic use of selon in French ("according to").

\section{COMMUNICATIVE SITUATION}

\subsection{The writing task at hand}

Students enrolled in their second year of the Translation or Applied Linguistics programs ${ }^{4}$ having a B2-C1 level of French according the Common European Framework of Reference for Languages (CEFR) had to write a 300-350 word essay about the novel Ni d'Ève ni d'Adam (Tokyo Fiancée) by Amélie Nothomb. After reading the book, their task was to describe the characters and give their opinions. They were asked to relate their comments to specific scenes in the novel. The aim of the latter instruction was to make sure the students would not go to the Internet and copy-paste a summary of the novel that they might have found on it. They were also told that their own comments would be welcomed. The objective of this written task was twofold: firstly, to get their comments about the novel and, secondly, to assess their writing skills. They had two weeks to do this homework. Our examples are taken from these essays and copied exactly as they appear in them, occasionally with some syntactic and/or grammatical errors.

\subsection{The communication contract}

As far as the communication contract is concerned, the teacher-learner scenario is defined by Charaudeau (1993) as an asymmetric relationship, in which the teacher assesses performance by comparing the student's "way of expressing" to another "way of expressing" that is considered to be exemplary. This assessment is done by grading and/or evaluation. The students must be able to demonstrate not only that they have acquired a knowledge of the book, but also their skills in the language of communication, which in this case is French. In short, they must be able to demonstrate, to the teacher, their ability in terms of the way of expressing by correctly following and interpreting the detailed instructions issued by the teacher. What is at stake here for the student is to secure a good grade for his or her essay in order to pass the subject (French) ${ }^{5}$. The teacher is the sole recipient of the essay and its hearer/addressee; the student must try to imagine what the teacher is expecting from him or her in order to take on a specific enunciative role in the writing process. As in any 
communication process, the contract plays a determining role on both parties involved as regards their positions, the objectives and the discursive forms.

\subsection{The corpus}

Certain expressive strategies are applied to written essays, based on the contractual framework defined above. Since we are dealing with an non-specialized scholarly discourse, where the knowledge that the students must be able to demonstrate is twofold, that of the language (grammar, vocabulary and spelling) and that of the book on which they are asked to comment, these discourses ${ }^{6}$ demonstrate a strong mediatized knowledge, showing a certain epistemic distance between the enunciator and his or her language production. This distance may be interpreted in two different ways, which are not mutually exclusive. First, it may show up as some kind of difficulty for the enunciator in taking full responsibility for the source of his or her statement. This difficulty may be due to the fact that the students are not native French speakers, meaning that it is more difficult for them to think subjectively in a foreign language. As Espuny pointed out (2000: 43) when mentioning the lack of subjectivity in his students' written productions, "the distance between them and their written discourse seems to be widened by the fact that French is not the language in which they normally think subjectively". Second, the distance may be explained by the fact that the student is trying to fulfil the expectation of objectivity that is demanded by the "scholarly" type of text that he or she has to produce, in which he or she has to demonstrate, justify, and objectively support the facts regarding his or her knowledge of the book about which he or she has to write.

In the framework of this study, we are going to examine the relationships between three forms of referred sources taking into account the following: 1) the communicative situation, 2) the modal value defined as the enunciator's expressive attitude (certainty/uncertainty) regarding his or her statement, 3) the alethic value, taken as the expression of the enunciator's commitment/noncommitment to his or her statement.

\section{ANALYSIS}

\subsection{DIFFERENT TYPES OF REFERENCING}

In this category, we have put evidential utterances about events in the story (4.1.1.), to the words of the narrator (4.1.2.) or to one of the characters of the novel (4.1.3.) referred to by the enunciator in order to justify his or her description of the characters. The common denominator of these forms is that the source does not come from a judgment made by the speaker (I think, I imagine, I believe, I 
deduce, etc.), but instead from a source/reference shared by the speaker and the hearer/addressee; the latter source functions as authority within the speaker's discourse.

\subsubsection{The shown source}

Theses tree structures have the following common structure [p, because $q]$ where $p$ is the locutor's or speaker's (L's) evaluation and q is the source of his or her evaluation. In other words, it is because of q that L says, deduces, affirms, concludes, thinks, believes, states, etc. p:

(4) « Rinri est la personnification de la culture japonaise: il est prudent, très poli et organisé. » ${ }^{7}$ (I)

[Rinri is the incarnation of Japanese culture: he is careful, very polite and organized.]

(5) «Amélie n'est pas une femme très affectueuse ; contrairement à Rinri qui est très tendre et démontre tout le temps à Amélie qu'il est amoureux d'elle : il la porte à de beaux endroits, il lui présente sa famille et, il la demande même en mariage. » (I)

[Amélie is not an affectionate woman; unlike Rinri, who is very tender and keeps showing Amélie that he is in love with her: he takes her to nice places, introduces his family to her, and has even asked her to marry him.]

(6) «Il s'agit d'une personne très attentionnée et gentille qui veut toujours rendre heureuse Amélie : il la conduit toujours chez elle et il veut l'emmener en voyage et l'étonner. » (III)

[He is a very considerate and kind person who always wants to make Amélie happy: he always takes her home and wants to take her on trips and surprise her.] (III)

Compared to what evidentiality is generally understood as, these examples constitute variants, and there are two reasons for this. First, because the source of knowledge does not come from the speaker, but instead from an external reference: scenes from the novel. Second, because no specific marker (whether morphological or lexical) signals the evidential status of the clause on the right. It is merely the common reference/source that indicates this. The interpretative phenomenon by which one attributes a sentence deprived of any evidential marker to the reporting exercise would create the conditions for the production of a pragmatically inferable evidentiality. In fact, the segments on the right function pragmatically as "sources" of the speaker's act of qualification. "Source" is understood here as something that motivates, triggers and underpins the speaker's evaluation. If the speaker depicts Rinri in the way he or she does, then it is because certain scenes from the novel have contributed to that depiction, and the speaker indicates which ones they are to the hearer/addressee. Having said that, not all colons introduce evidential segments, as examples (7) and (8) show:

(7) Tout était en solde: les livres, les cassettes, les disques et les revues. 
[Everything was on sale: books, cassettes, records and magazines.]

(8) Jean ne peut pas courir : il s'est cassé la jambe.

[Jean can't run: he's broken his leg.]

In example (7), the segment that comes after the colon specifies what the cataphoric pronoun "everything" (tout) is referring to by listing the objects. In example (8), without any context, one cannot stipulate that the cause of he's broken his leg has an evidential status of reference to a source (common or individual).

In contrast, in examples (4), (5) and (6), there is indeed a common source shared by the speaker and the hearer/addressee of the message (the teacher), whose pragmatic function is to show the hearer where the speaker drew his or her information from to assert that Rinri is the incarnation of Japanese culture or that Rinri ... is very tender and keeps showing Amélie that he is in love with her, etc.

From an epistemic and alethic viewpoint, these evidential sequences do not present any mark of subjective evaluation or of the speaker taking ownership, as would have been the case if the speaker had used I imagine/I see/I find that Rinri is kind because he shows that he has feelings. The speaker does not need to do so, since this is a given fact; it is part of the world to which he is referring. The sole responsibility of the utterer is in the way he chooses to justify his or her statement and the choice of passage from the novel that he or she quotes in order to illustrate his or her statement.

However, at an argumentative and pragmatic level, it should be said that these references to the source have an epistemic value of reliability and legitimacy because their function is to support and to validate the speaker's evaluation and the grounds for his or her opinion.

The same goes for the locutor's assessment. While there is strictly speaking no ownership of the act of assertion (the descriptive form of the act $\mathrm{p}$ leaves the act void of any interpretation in terms of thought or judgment), it could be said that the speaker implicitly stands as the guarantor of his or her act since it functions pragmatically as true and certain.

Regarding the particular choice of this type of evidentiality, it may have been motivated by the pragmatic effects that it has. By choosing to refer to scenes from the novel and to leave out any personal perception (I read, I think, I believe, I consider, etc.), the student shows some desire for objectivity and rigour in the sense that the book — and not his or her own perception — is the source of his or her act. 
We would therefore say that these evidential acts do not contain any evidential, modal or alethic marker. Rather, they function pragmatically as evidential and epistemic modals bearing the value of well-grounded information, and belong to the alethic domain, insofar as their function is to bring legitimate (therefore true) evidence or proof to the argument.

\subsubsection{The quoted source}

Unlike the case in the previous examples, here we do not have to interpret whether the acts or statements introduced by the prepositional syntagms "for example" or by the adverb "like" (comme) are evidential segments or not, because the parts in italics indicate that these segments have been borrowed, and that the enunciator is therefore not the first-hand source of the information that he or she mentions in his or her examples. The examples on which the enunciators rely in order to illustrate the truth or the relevance of their statements (In this novel, we can find many references to Japanese culture; She is very stubborn; Rinri is really Japanese) are literal quotes stemming from another enunciative unit: the words of the narrator of the novel, which are juxtaposed to the students' own.

(9) «Dans ce roman, on peut trouver ${ }^{8}$ beaucoup de références aux traditions ou stéréotypes de la culture japonais. Par exemple, à la p. 38, il y a une exemplification qui montre l'obéissance et tradition du Japon : les Japonais faisaient les choses parce que cela se faisait. » (II)

[In this novel, we can find many references to, or stereotypes referring to Japanese culture. For example, on page 38, there is an example showing obedience and Japanese tradition: the Japanese did things a certain way because that's how things were done there.]

(10) «Elle est très têtue ; par exemple elle ne veut pas sortir du furo lorsque, elle, et Rinri sont à l'île de Sado, et elle a aussi peur du mariage. » (III)

[She is very stubborn; for example, she doesn't want to get out of the furo when she and Rinri are on Sado island, and she is also afraid of marriage.]

(11) « C'est un authentique japonais bien qu'il n'aime pas la manière d'être des japonais et il suit ses traditions, comme se récurer entièrement dans le lavabo avant d'entrer dans le bain.»(VII)

[He is really Japanese, even though he doesn't like the way the Japanese are, and he follows their traditions, such as completely scrubbing himself off before entering the bathtub.]

What is striking in example (9) is the enunciator's difficulty integrating or embedding the various quotations or (voices) to which he or she is referring into his or her own discourse. The enunciator 
literally gives someone else the voice, who, in this case, is the narrator of the novel, and cannot take ownership over what is being said; the enunciator cannot continue, from what is being said. The sole responsibility of the enunciator is the juxtaposition of two independent acts. Indeed, the situation would have been quite different if, for instance, instead of having a statement like (9), we had had (9'):

(9') Dans ce roman on peut trouver beaucoup de références à la culture japonaise. Par exemple, lorsque la narratrice dit que les Japonais font les choses parce que cela se fait cela montre le caractère traditionnel et figé de ses gens.

[In this novel, we can find many references to Japanese culture. For example, when the narrator says that the Japanese do things a certain way because that's how things are done there, it shows the traditional and rigid character of the Japanese.]

Reported in an indirect form, such a discourse would have shown greater integration of the other discourse, both semantically and syntactically. If we consider the fact that indirect discourse "is, explicitly, to take a stand as to the meaning of the act of speech" Authier Revuz (1978: 66) and that it refers to "a sole situation of enunciation: the quoting discourse" (Maingueneau 1993 [1986]: 97), the statements we have and which are evidential in nature never reflect "one's taking a stand on another act of speech" (Guentchéva 1994: 12). Furthermore, the enunciator, when expressing him or herself via indirect speech, guarantees the level of truth only in relation to what he or she is reporting (Martin 1992: 107), whereas evidential discourse does not bear any guarantee whatsoever as to the reported statement, because it places the statement beyond any kind of assumption, that is to say, beyond any assumption regarding its "true" or "false" nature. We can therefore say that the enunciator does not take responsibility for, or does not commit him or herself to the content of his or her statement, and puts some distance between him or herself and the facts that he or she is reporting. If indirect speech is expressed via subordinate clauses, the mediative values are transmitted via independent clauses. This particular use of "referred discourses" shows how difficult it is for the enunciator to be subjectively involved in the universe to which he or she is referring, and to somehow make it his or her own; either because the reference is a supreme authority at which he or she can only point but never touch (like the sun for instance), or because personal involvement would require some kind of integration or assimilation, an effort that he or she is not prepared to make.

In examples (10) and (11), the evidential segments are far better integrated into the discourse of their enunciators. In both cases, all the mediatized discourses support the way in which the enunciators 
perceive the characters of the novel. In this respect, (except for 10) they hold both modal and alethic values; modal, because they show guarantees brought forth by the enunciator to support his or her judgement, and alethic, because although the enunciator ${ }^{9}$ does not commit to the discourse segments, they are presented as being true and authentic since they are taken from the book on which the enunciator is commenting. The direct mode of presenting evidence or proof (quotes in italics) serves to highlight the authenticity of their references.

\subsubsection{Borrowed knowledge by "according to $X$ " (selon $X)$}

In this series of examples, the evidential forms introduced by "according to X" (selon $\left.X^{10}\right)$ show that $\mathrm{p}$ has been borrowed from someone else (mediative feature) and that $\mathrm{p}$ is true in an enunciativeepistemic world (alethic feature). All of them present a discourse that is not theirs. Some examples are given below:

(12) «Amélie est une fille indépendante qui aime voyage. Rinri est un garçon gentil, chevalier et selon Christine, une amie d'Amélie, il est trop beau. » (II)

[Amélie is an independent girl who loves to travel. Rinri is a nice boy, a gentleman, and according to Christine, a friend of Amelie's, he is very handsome.]

(13) « Rinri est un garçon maigre et haut, d'origine sociale riche. Selon Amélie, il est le garçon le plus gentil qu'elle a jamais connu. » (XII)

[Rinri, is a skinny, tall boy, belonging to the wealthy social class. According to Amélie, he is the kindest boy she has ever met.]

(14) «Selon Amélie, il est distingué et immobile et il a la nuque raide et rasée de près. » (XIII)

[According to Amélie, he is distinguished and immobile, the nape of his neck is stiff and clean shaven.]

(15) «Rinri, c'est un garçon japonais qui est plutôt maigre, en même temps qu'il est grand, assez grand pour être japonais, selon la protagoniste. » (XIV)

[Rinri, is a Japanese boy who is rather thin but quite tall at the same time, rather tall for a Japanese person, according to the main character.]

(16) «Rinri est un garçon de 20 ans qui étudie le français à l'université. Il est le fils d'une riche famille et il habite dans un «château », selon Amélie. » (XV)

[Rinri is a 20 year-old boy who studies French at university. He is the son of a wealthy family and lives in a "castle" according to Amélie.]

(17) «Rinri est né au Japon, il provient d'une famille riche et à vingt ans lorsqu'il rencontre Amélie. Il est très mince, a un style moderne juvénile et a une Mercedes blanche. Selon Amélie, il portait toujours les mêmes vêtements... » (XVI) 
[Rinri was born in Japan to a wealthy family, and is 20 years old when he meets Amélie. He is very thin, has a modern and youthful style and drives a white Mercedes. According to Amélie, he was always wearing the same clothes....]

(18) «Amélie est d'origine belge et a vingt-et-un ans. Sa passion est l'écriture et aussi la littérature. Selon Rinri, elle est belle mais pas assez moderne. Elle est très sociable, mais les nippons ne le sont pas trop, et donc elle se sent incommode avec eux. Elle est aussi intelligente car elle apprend vite le japonais. » (XVI)

[Amélie is of Belgian origin and she is 21 years old. She has a passion for writing and literature too. According to Rinri, she is pretty, but not trendy enough. She is very sociable, but the Japanese are not particularly so, so she doesn't feel very at ease with them. She is also smart because she's learning Japanese fast.]

(19) «C'est un homme très gentil qui, selon Amélie, n'a aucun défaut, sauf le fait qu'il est trop bon. Son innocence et le manque de compétences communicatives d'Amélie lui posent des problèmes pour bien comprendre les habitudes occidentales. » (XVII)

[He is a very kind man, who, according to Amélie, has no defects, except that he is too kind. His innocence and Amélie's lack of communication skills prevent him from understanding Western customs.]

We can observe that these prepositional syntagms are either placed within the sentence, such as in (12), (15), (16) and (19), or outside the sentence, such as in (13), (14), (17) and (18), and that they allow the introduction of a range of enunciations (Schrepfer 2005) that are different from the main enunciator's. From the three main meanings that "according to" (selon) ${ }^{11}$ can have, our examples all show its enunciative use, or use referring to borrowed information (Schrepfer 2005: 11). They are used to report a word such as (16), or the content of what an utterer other than the speaker has stated. In this respect, they establish a relationship within the discourse. However, in contrast to the discourses, which are reported indirectly, these forms introduce two situations of enunciation highlighting the distance between the enunciator and the original utterer. What is their pragmatic function in the students' discourse?

In examples (12), (13), (14), (17), (18) and (19), they serve the purpose of completing the description of the characters. This description is given from various angles, either from the main utterer's viewpoint, or based on the opinion of one of the characters from the novel. Let's take example (12). First we see the enunciator's viewpoint (Rinri is a nice boy, a gentleman) and then the description of this character is completed by he is very handsome, based on a remark made by Christine, a friend of Amélie's, which specifies the criterion according to which this statement is true. However, among all the examples (12-19), a difference in the use of "according to" (selon) can be observed. On the one hand, some enunciators add a degree of diversity to the viewpoints but neither integrate it into the content of their discourse nor commit to it; this is the case in examples (12), (13), (14), (17), (18) and 
(19). On the other hand, there are examples where such enunciative diversity is integrated into the content of the discourse and is used as an argument; this is the case in examples (15) and (16). While the former examples do not function as modality in its strict sense, the latter do. In order to verify this, we have modified the two values of "according to" (selon) and performed the test of negation and interrogation. The negation test shows that L (the speaker) can easily negate the clause after "according to" (selon):

(12') Selon Christine Rinri est très beau ... mais je n'en crois rien.

[According to Christine, Rinri is very handsome... but I don't believe so.]

This test shows that the fact of reporting E's viewpoint is by no means any guarantee that L will in turn guarantee this statement, which allows him or her to refute it. The same goes for all the examples of the first group. However, in the modal use of "according to" (selon) (examples (15) and (16)) it is difficult for $L$ to negate the statement without causing contradiction:

$\left(15^{\prime}\right) *$ Rinri, c'est un garçon japonais qui est plutôt maigre, en même temps qu'il est grand, assez grand pour être japonais, selon la protagoniste... mais je n'en crois rien.

* [Rinri, is a Japanese boy who is rather thin but quite tall at the same time, rather tall for a Japanese person, according to the main character..., but I don't believe it.]

$\left(16^{\prime}\right)$ * Il est le fils d'une riche famille et il habite dans un «château », selon Amélie, mais je n'en crois rien.

* [He is the son of a wealthy family and lives in a "castle" according to Amélie..., but I don't believe it.]

The test of asking the question (Do you think that...?) clearly shows that "according to Christine, p" is asserting that according to Christine, $\mathrm{p}$, but not thinking $\mathrm{p}$.

Hence the impossibility of the following sequence:

(12'”) A - Penses-tu que Rinri est très beau ?

B. - * Selon Christine, oui.

A - Do you think that Rinri is very handsome?

B. - * According to Christine, yes.

Whereas in (15) and (16) the enunciator assumes and thinks p:

(15') A - Penses-tu que Rinri est grand ?

B. - Selon moi, oui. Et selon la protagoniste assez grand pour être japonais.

A - Do you think the Rinri is tall?

B. - According to me, yes. And, according to the main character, quite tall for a Japanese person. 
We can therefore say that the modal value of "according to X" (selon X) is not fixed. It depends on its use and its context. In examples (12), (13), (14), (17), (18) and (19), the utterers do not commit themselves to the true or false nature of the statements they emit since they do not assume them, but instead merely transmit them. They neither commit their subjectivity to them, nor take responsibility for them. This is why Schrepfer (2005: 23) asserts that "according to X" (selon X) is not a modality in the strict sense. The instruction the utterers bear is conditioned by the truth; they only state the criterion based on which the clause is true, and that criterion is not theirs but another enunciator's. If modal value exists, it is indirect, and has to do with the pragmatic effect its use brings about from an argumentative viewpoint, that is to say, to add legitimacy to their discourse by relying on information voiced by a source bearing authority (a book). However, in examples (15) and (16), the occurrences of "according to X" (selon X) have modal value. Besides specifying the truth condition, the speaker shares it and takes responsibility for it. The introduction of another voice (that of the narrator) comes as a further argument to support the speaker's evaluation (he is rich or he is tall). From an alethic viewpoint, these enunciations are true for the utterers in (15) and (16).

Turning to the question about why students use these enunciative adverbs, we can explain it on the basis of our initial hypothesis. Given the communicative situation they were in, the students had to provide evidence or proof and justify their comments to the hearer/addressee that they had created. They did so by adding another enunciator, shown as being sure about $\mathrm{p}$ due to the supposed objectivity of the way they obtained the information. This allows them to add legitimacy to their discourse while showing traceability at the same time, that is to say, by indicating the person through whom they got this information. In some discourses, these borrowings are presented as completely dissociated, in others they are better integrated into the argumentative line of the main speaker.

\section{Conclusions}

We proposed an evidential reading of three types of reference found in copy written by students, the main function of which was to provide evidence or proof - through quotes, references to passages from the book or borrowing ("according to") — of the grounding of the conclusions that the speakers drew in relation to the description of characters from the novel in question.

Given the type of discourse analysed, we introduced a variant into the strict definition of evidentiality: the notion of why the speaker knows (or thinks) what he or she knows (thinks) and why the speaker says what he or she says instead of "how one has knowledge of what one is saying". 
A particular feature of these references is that they constituted knowledge that was either common or shared by the speaker and the hearer/addressee within the communicative situation. From this viewpoint, it was objective and reliable knowledge because it belonged to the world (represented) with which it was concerned. It was evidential because the speakers presented it as something that motivates, i.e., that was at the origin of their opinions, of their qualifications and their descriptions of the characters from the novel. In fact, it was because [Rinri] always takes [Amélie] home and wants to take her on trips that the speaker could conclude (think) that [Rinri] is very tender and keeps showing Amélie that he is in love with her. While one cannot, strictly speaking, talk of abductive inference between $q$ (the characters' actions and) $\mathrm{p}$ (the conclusion that the speaker drew), one can talk of cause, reason and motivation that induced the speaker to say (think) p.

In relation to the communicative situation interface (pragmatic) and types of source, the latter were of a "reference" type because they constituted knowledge; the common and objective knowledge acquired by reading the novel. However, the forms that the speakers chose in order to refer to this common source were unique to each of them and thus verified our initial hypothesis. The considerable epistemic distance separating the utterer from the knowledge to which he or she is referring can be explained by the representation that he or she forms of the teacher's request. Because of what was at stake, the students tried to provide as much evidence or proof as possible to support what they were saying, thereby legitimizing their description of the characters; moreover, such evidence or proof had to be objective. They therefore took, as the source of knowledge, those passages from the novel that could justify their own statements. However, the form taken by some of these references, particularly in examples (5), (9) and (12), mostly underscores the difficulty that some students had in subjectivizing their knowledge, that is to say, in taking full responsibility for what they were saying and guaranteeing their statements, either because they did not feel that they had the legitimacy to do so, or because this would have implied taking ownership of the knowledge, and that they were not prepared to make that effort. They may also have thought that providing statements in this way would give greater weight to their discourse.

Finally, concerning the close link established between evidentiality, epistemic modality and the alethic value of these structures, we would say that, because the source constituted knowledge that was common and shared by the actors of this interaction, said source was reliable and characterized by the fact that it was objective and not subjective (Cornillie 2009). Reliability was therefore an intrinsic property of the nature of the source (evidential). However, the argumentative use of these "reliable" references in the students' discourse made them acquire an alethic and epistemic function. 
Alethic, because the source functioned as true, since it was part of the accepted world as such, beyond any evaluation in terms of possibility or probability. In addition, it was because the source that motivated or underpinned the speaker's conclusion was true that it legitimated and proved the validity (or truth) of the speaker's opinion. The epistemic dimension of the reference to the source was connected with the hearer/addressee of the message. By showing the teacher what motivated his or her opinion, the student gave him or her the opportunity to evaluate the relevance of it in terms that were more or less fair, probable, true or possible. In all cases, the alethic and epistemic dimensions appeared indirectly as pragmatic effects of their argumentative function in the discourse.

\section{References}

Authier Revuz (1978) “Les formes du discours rapporté”, DRLAV, T. 17: 1-87.

Barbet, C. (2012) “Devoir et pouvoir, des marqueurs modaux ou évidentiels ?”, Langue française, 173/1: 49-63.

Borillo, A. (2005) “[d'après $N]$, complément circonstanciel et marqueur énonciatif d'évidentialité”, I. Choi-Jonin et al. (eds.), Questions de classification en linguistique : méthodes et descriptions. Mélanges offerts au Professeur Christian Molinier, Bern, Peter-Lang: 39-53.

Charaudeau, P. (1993) "Le contrat de communication dans la situation classe" in Inter-Actions, J.F. Halté, Université de Metz. http://www. patrick-charaudeau.com/Le-contrat-de-communication-dans.html

Charolles, M. (1997) "L'encadrement du discours, univers, champs, domaines et espaces", Cahier de Recherche Linguistique 6, U.R.A. 1035 LanDisCo, Université de Nancy 2.

Cornillie, B. (2009), "Evidentiality and epistemic modality: On the close relationship of two different categories", Functions of Language 16 (1): 44-62.

Coltier, D. (2000) Analyse sémantique de «selon». Quelques propositions, Doctoral thesis, Université de Nancy 2.

Coltier, D. \& Dendale, P. 2004 "La modalisation du discours de soi : éléments de description sémantique des expressions pour moi, selon moi, et à mon avis", Langue française 142: 41-57.

De Saussure, L. (2012) "Modalité épistémique, évidentialité et dépendance contextuelle", Langue française, 173/1: 131-143.

Dendale, P. (1993) "Le conditionnel de l'information incertaine: marqueur modal ou marqueur évidentiel ?", G. Hilty (ed.), Actes XX $X^{o}$ Congrès International de Linguistique et Philologie Romanes: Tübingen, Franck, vol. 2: 165-176.

Dendale, P. (1994) “Devoir : marqueur modal ou évidentiel ?”, Langue française, 102: 24-40. 
Dendale, P. \& Tasmowski, L. (2001) Introduction : Evidentiality and related notions, Journal of Pragmatics 33: Elsevier.

Dendale, P. \& Van Bogaert, J. (2012) "Réflexions sur les critères de définition et les problèmes d'identification des marqueurs évidentiels en français", Langue française 173: 13-29. DOI: 10.3917/lf.173.0013.

Dendale, P. \& Tasmowski, L. (eds.) (1994), Langue française 102 : Les sources du savoir et leurs marques linguistiques, Paris: Larousse.

Ducrot, O. (1980) Les mots du discours, Paris: Minuit.

González, Montserrat (2011) "Indirect evidence in Catalan: a case study". In Cots, Josep María, Payrató, Lluís (eds.): The Pragmatics of Catalan. Berlin, Mouton de Gruyter: 145-172.

Espuny, J. (2000) "La subjectivité perdue dans l'écrit de l'étudiant, ou le trésor de la subjectivité oubliée", La philologie française à la croisée de l'an 2000 : panorama linguistique et littéraire, coord. by Montserrat Serrano Mañes et al. Vol. 2: 41-51.

Guentchéva, Z. (1994) "Manifestations de la catégorie du médiatif dans les temps du français" Langue française 102: 8-23.

Hardman, M. J. (1986) "Datasource marking in the Jaqi language". In W. Chafe \& J. Nichols (eds.): Evidentiality: The linguistic coding of epistemology, 113-136. Norwood, NJ: Ablex.

Kronning, H. (2003) "Modalité et évidentialité,, in M. Birkelund, G. Boysen \& P. S. Kjærsgaard (eds.), Aspects de la modalité, Tübingen: Max Niemeyer: 131-152.

Kronning, H. (2004) "Modalité et mediation épistémique", in R. Delamotte-Legrand (eds.), Les Médiations Langagières, des faits de langue aux discours, Vol.1, Université de Rouen: Dyalang:3565 .

Maingueneau, D (1993) Éléments linguistique pour le texte littéraire. Paris: Dunod.

Martin, R. (1992 [1983]) Pour une logique du sens, Paris: PUF.

Miche, E. \& Lorda, C. (2014) "Probability and certainty markers in French and in Spanish (sans doute / sin duda)", Langage and Dialogue, John Benjamins: 42-57.

Nothomb, Amélie (2007) Ni d'Ève ni d'Adam, Paris: Albin Michel.

Nuyts, J. (2001) Epistemic modality, language, and conceptualization: A cognitive-pragmatic perspective. Amsterdam: Benjamins.

Schrepfer, G. (2005) La portée phrastique et textuelle des expressions introductrices de cadres énonciatifs: les syntagmes prépositionnels en selon X. Doctoral thesis, Université de Paris 3, la Sorbonne-Nouvelle. 


\footnotetext{
${ }^{1}$ I would like to thank my two anonymous readers for their relevant comments, which allowed me to fine-tune certain aspects of the article.

${ }^{2}$ Guentchéva (1994: 9) prefers the term "mediative" to "evidential" in order to avoid the opposite meaning this latter has in French, where one might think that the category is related to the notion of evidence, however, "mediative" is the opposite of evidence.

${ }^{3}$ The linguistic marker sans doute (Miche \& Lorda 2014), encoding two semantic domains: evidential and epistemic.

${ }^{4}$ They are students at Pompeu Fabra University in Barcelona, where I teach.

${ }^{5}$ Since the Bologna Process, the grades obtained for various tasks make up half the final grade.

${ }^{6}$ We prefer the notion of "discourse" to that of "text" when referring to student essays, because this term refers to a trace of language that is neither fixed nor frozen, which someone will read and interpret.

${ }^{7}$ One might question whether the statement he is careful, very polite, organized is a reported fact or an inferred one. No explicit indication is given to enable a decision to be taken on this.

${ }^{8}$ The modal verb can (pouvoir) (as in one can find / on peut trouver) followed by the verb find /trouver, takes away all personal apprehension from the part of the enunciator towards his or her remark, as this situates it within a sphere of possibility to which he or she is not committed, or for which he or she does not take full responsibility, as is shown by the use of the impersonal pronoun "one" (on).

${ }^{9}$ Somewhat as if his or her commitment were relegated to that of the narrator of the novel. Students hide behind the statement of the latter.

${ }^{10}$ Many authors have analyzed this mark (Coltier 2000, Kronning 2003, Dendale 1993, Schrepfer 2005). Our comments are inspired by their work.

${ }^{11}$ Meaning, respectively, "compliance" (Prepare the dish according to the recipe), "dependence" (depending on the news, I will either come or I will continue my journey), "attribution" (According to Max, Marie has a lover). These three meanings correspond to the three glosses proposed by Charolles (1997): in accordance with, depending on, according to
} 